\title{
Implementasi Kebijakan Online Single Submission pada Pelayanan Perizinan Usaha (Studi Kasus di DPMTSP Kota Bandung \& Kabupaten Bandung)
}

\author{
${ }^{1}$ Joni Dawud, ${ }^{2}$ Rodlial Ramdhan Tackbir Abubakar, ${ }^{3}$ Deni Fauzi Ramdani \\ ${ }^{1}$ Politeknik STIA LAN Bandung; jonidawud@poltek.stialanbandung.ac.id \\ ${ }^{2}$ Politeknik STIA LAN Bandung; rodlial@poltek.stialanbandung.ac.id \\ ${ }^{3}$ Politeknik STIA LAN Bandung; deni.fauzi@ poltek.stialanbandung.ac.id
}

\begin{abstract}
The Central Government is working on the development of the economic sector by developing suitable legality instruments, especially in the management of business licenses. The government has issued the Regulations concerning Electronic Integrated Business Licensing Services. Online Single Submission (OSS) is an application that can be used for all business registration and application processes, and other licensing applications in the business licensing service. This research aims to examine how the implementation of OSS on business licensing services in Bandung city and Bandung Regency. This research employed a descriptive qualitative approach. The data collection techniques were done through interviews, documentation, and observation. The research results showed that business licensing services using online single submissions have already been good, but these efforts have not been running optimally. There are still obstacles that are often faced by DPMPTSP Bandung City and Bandung Regency, especially related to supporting facilities and disharmony between central and regional regulations concerning the implementation of the online single submission.
\end{abstract}

Keywords: Policy Implementation, Online Single Submission, Public Service, Business Licensing Services.

\section{Pendahuluan}

Sejak Tahun 2018, Pemerintah Pusat tengah mengupayakan pengembangan pada sektor ekonomi berupa penyiapan instrumen legalitas yang baik, khususnya pada pengurusan perizinan usaha yaitu dengan diterbitkannya Peraturan Pemerintah Nomor 24 Tahun 2018 tentang Pelayanan Perizinan Berusaha Terintegrasi Secara Elektronik (Robby \& Tarmini, 2019). Perizinan usaha ini merupakan salah satu instrumen kebijakan pemerintah untuk dapat melakukan pengendalian atas aktivitas ekonomi yang menyebabkan dampak negatif pada pihak ketiga atau dikenal dengan kata eksternalitas negatif, yang mungkin saja timbul disebabkan adanya kegiatan sosial maupun ekonomi (Izhandri \& Harahap, 2019). Perizinan juga dapat digunakan sebagai alat untuk mendapatkan kekuatan hukum/ legalitas atas kepemilikan atau penyelenggaraan aktivitas usaha. Sebagai alat untuk mengontrol, perizinan perlu didasarkan atas pertimbangan yang logis dan tercantum dalam sebuah regulasi pemerintah sebagai salah satu pedoman. Oleh karena itu, tanpa adanya pertimbangan yang logis dan rancangan regulasi yang eksplisit, maka legalitas usaha akan kehilangan nilainya sebagai sebuah alat untuk membela kebutuhan usaha atas perilaku yang ditimbulkan oleh individu (Sutedi, 2010). Berdasarkan regulasi tersebut, maka kini seluruh layanan legalitas usaha menjadi terpusat melalui suatu Sistem yang kita kenal dengan sebutan Perizinan Berusaha Secara Elektronik atau dalam Bahasa asing disebut Online Single Submission (OSS). 
Berdasarkan Peraturan Pemerintah Nomor 24 Tahun 2018 Tentang Pelayanan Perizinan Berusaha Terintegrasi Secara Elektronik, diketahui bahwa Online Single Submission (OSS) adalah sebuah sistem yang dapat dipakai untuk melakukan segala macam jenis proses registrasi dan pengusulan legalitas bisnis serta pengusulan perizinan yang lain, yang tertera pada layanan legalitas usaha dengan alamat website http://oss.go.id (Maulida, 2019). OSS pertama kali diluncurkan oleh pemerintah pusat yakni pada tanggal 8 Juli 2018 yang kemudian diterapkan satu bulan kemudian di berbagai daerah, termasuk beberapa daerah diantaranya yaitu Kota Bandung dan Kabupaten Bandung. Adapun 6 Sistem dalam Online Single Submissions terlebur dan menjadi portal dari sistem layanan pemerintahan yang ada pada K/L dan Pemerintah Daerah baik Kabupaten, Kota, maupun Provinsi. Sistem yang ada pada Online Single Submissions ini juga merupakan single reference (pedoman utama) dalam pembuatan legalitas usaha. Apabila K/L dan Pemda punya beberapa sistem legalitas elektronik, maka sistem Online Single Submissions akan melakukan peleburan pada satu portal sistem legalitas elektronik yang ditetapkan oleh K/L dan Pemda yang bersangkutan.

Mengacu pada salah satu fungsi ASN (Aparatur Sipil Negara) sebagai pelayan publik, Pemerintah Daerah Kabupaten Bandung dan Pemerintah Kota Bandung selaku instansi penyelenggara pelayanan publik di daerah, memiliki kewajiban untuk menyelenggarakan pelayanan publik kepada masyarakat di daerahnya masing-masing. Salah satunya yaitu terkait layanan legalitas usaha terintegrasi secara elektronik. Namun sebagaimana kita ketahui bahwa pelaksanaan sebuah kebijakan yang baru dibuat tidak terlepas dari hambatan-hambatan yang mempengaruhi tujuan dan penyelenggaraan kebijakan itu sendiri. Adapun kendala-kendala tersebut diantaranya yaitu:

1. Kecenderungan pemohon izin secara eletronik baik di Kota Bandung maupun Kabupaten Bandung medapati peningkatan secara drastis yang mana sejak awal hanya berkisar puluhan saat peluncuran pertama OSS dan terus meningkat sampai mencapai ribuan pemohon pada bulan-bulan berikutnya setelah peluncuran. Hal ini menimbulkan ketidakseimbangan jumlah Sumber Daya Manusia Aparatur yang ada dengan tuntutan jumlah pelayanan yang semakin bertambah.

2. Merubah sistem pelayanan manual kepada sistem daring (online) membutuhkan masa transisi yang relatif lama, Kabupaten Bandung sendiri sudah melakukan transisi sejak Tahun 2017.

3. Banyaknya penilaian yang diberikan oleh beberapa K/L, LPNK, dan LNS seringkali membuat instansi penyelenggara layanan mengalami disorientasi pelayanan, sehingga mengabaikan hal-hal substansial pelayanan yang efeknya langsung dirasakan oleh penerima layanan yaitu masyarakat

4. Belum adanya regulasi turunan terkait $O S S$ sehingga menimbulkan perbedaan tafsir antara pemohon dan petugas pemberi layanan.

5. Masyarakat masih mengeluhkan adanya prosedur dan mekanisme kerja pelayanan yang dinilai masih berbelit-belit, dan belum menjamin kepastian (hukum, waktu, dan biaya) walaupun pelayanan perizinan berusaha sudah terintegrasi secara elektronik.

Meskipun kendala-kendala tersebut terjadi di lapangan, akan tetapi responsibilitas serta peran Dinas Penanaman Modal dan Pelayanan Terpadu Satu Pintu Kota Bandung dan Kabupaten Bandung tetap berjalan didasarkan pada tupoksi serta regulasi yang ada untuk dapat menciptakan pelayanan prima. Adapun untuk mengukur kesiapan pemerintah Kota Bandung dan Kabupaten Bandung dalam menerapkan kebijakan OSS, Penulis menggunakan teori yang dikemukakan oleh Edward III yang menjelaskan bahwa penerapan kebijakan diukur melalui oleh empat dimensi (Nugroho, 2012), sebagai berikut : 
1. Komunikasi, yaitu dimana sebuah kesuksesan kebijakan mengharuskan agar pelaksana memahami apa yang semestinya dilaksanakan, dimana yang menjadi sasaran dan tujuan kebijakan harus disampaikan kepada target group (kelompok sasaran), yang tentunya akan berdampak pada berkurangnya bias pelaksanaan kebijakan tersebut (R. Abubakar, 2019).

2. Sumberdaya, setelah isi dari kebijakan telah disampaikan secara konsisten dan jelas, maka perlu didukung oleh sumberdaya untuk melaksanakan kebijakan tersebut sehingga pelaksanaan kebijakan menjadi efektif,. Sumber daya yang dimaksud disini dapat berwujud SDM yakni pegawai/ aparatur dalam sebuah instansi, dapat juga berwujud sarana prasarana yang dimiliki, serta dapat berwujud sumber daya finansial atau yang kita kenal dengan anggaran.

3. Disposisi, merupakan karakteristik atau watak yang dimiliki oleh pelaksana kebijakan, seperti kejujuran, komitmen, dan demokratis. Jadi, apabila pelaksana kebijakan mempunyai disposisi yang bagus, maka pelaksana kebijakan tersebut dapat menerapkan kebijakan yang sesuai dengan yang diinginkan oleh perumus kebijakan. Saat pelaksana kebijakan mempunyai perbuatan adan pandangan yang berbeda dengan perumus kebijakan, maka dikhawatirkan proses pelaksanaan kebijakan tidak dapat mencapai tujuannya (Pikri, Abubakar, \& Adawiyah, 2019).

4. Struktur Birokrasi, yang mana hal ini merupakan sebuah struktur dalam organisasi yang memiliki tugas untuk melaksanakan kebijakan dan sangat berpengaruh terhadap pelaksanaan kebijakan. Adapun dimensi-dimensi dari struktur birokrasi ini yaitu fragmentasi dan SOP (Standard Operating Procedure). Struktur birokrasi yang gemuk namun tidak kaya fungsi mengarah pada pelemahan pengawasan dan terjadinya red-tape dalam sebuah birokrasi, yaitu sebuah alur pelayanan yang kompleks dan rumit, yang membuat kegiatan birokrasi menjadi kaku (Sembiring, 2018). Adapun hal-hal penting yang perlu ada dalam sebuah struktur birokrasi yaitu meliputi, aparatur yang mumpuni disertai kompetensi yang baik untuk melaksanakan pekerjaan-pekerjaan dan wewenang dalam rangka menyelenggarakan pelayanan public yang prima.

Penelitian mengenai implementasi OSS ini sebelumnya pernah dilakukan oleh (Fadhilah \& Indah Prabawati, 2019) di Kabupaten Nganjuk dengan hasil penelitian yang menunjukan bahwa OSS di DPMPTSP Kabupaten Nganjuk sudah diterapkan, namun masih terdapat kendala dalam sosialisasi yang tidak sepenuhnya masyarakat mendapatkan informasi tersebut. Penggunaan layanan perizinan berusaha melalui OSS juga menimbulkan kekhawatiran salah input terkait dokumen-dokumen yang dijadikan syarat, sehingga mayoritas calon pelaku usaha perseorangan di Kabupaten Nganjuk lebih memilih mendatangi langsung DPMPTSP Kabupaten Nganjuk. Sementara untuk Sumber daya manusia di DPMPTSP Kabupaten Nganjuk dapat dikatakan sudah cukup memadai untuk mengelola berbagai macam perizinan. Namun dalam hal Fasilitas pendukung diperlukan adanya peningkatan khususnya dalam hal jaringan internet yang sering mengalami eror atau koneksi buruk. Selain itu, dimensi disposisi dalam hal pengangkatan petugas dilakukan secara formal dengan diterbitkannya Surat Kepala Dinas DPMPTSP Kabupaten Nganjuk, dan tidak ada insentif yang didapatkan oleh petugas yang bekerja untuk mengelola OSS di DPMPTSP Kabupaten Nganjuk. Selain itu, dalam hal Struktur birokrasi sudah dilaksanakan berdasarkan tupoksi yang seharusnya. 
Penelitian mengenai implementasi OSS lainnya dilakukan oleh (Robby \& Tarmini, 2019) di Kabupaten Bekasi yang menerangkan dalam hasil penelitiannya bahwa dampak yang ditimbulkan dari penerapan OSS terhadap percepatan perijinan berusaha di Kabupaten Bekasi dapat dikatakan sudah baik, akan tetapi upaya-upaya yang telah dilakukan dinilai belum optimal, kendala-kendala masih kerap ditemu oleh DPMPTSP Kabupaten Bekasi terutama dalam hal sarana prasarana. Penelitian terkait pelaksanaan OSS selanjutnya dilakukan oleh (Assegaf, Julianti, \& Sa'adah, 2019) di Provinsi Jawa Tengah yang dalam hasil penelitiannya mengemukakan bahwa OSS menjadi salah satu solusi untuk mengatasi keluhan yang selama ini disampaikan oleh para pelaku bisnis. DPMPTSP Jawa Tengah menjadi fasilitator kelancaran pelaksanaan sistem ini. Adapun kendala yang ditemui DPMPTSP Jawa Tengah yaitu banyaknya para pelaku bisnis yang belum memahami sistem OSS ini, oleh karena itu, usaha sementara yang dilakukan DPMPTSP Jawa Tengah yaitu dengan cara memberikan pendampingan kepada pelaku bisnis dan melakukan koordinasi lembagalembaga terkait

Mengacu pada penelitian terdahulu yang telah penulis sampaikan, maka dapat diketahui bahwa terdapat beberapa kesamaan dan perbedaan antara penelitian tersebut dengan penelitian yang penulis buat. Adapun kesamaannya yaitu meneliti terkait implementasi Operation Single Submission dan Menggunakan teori Edward III untuk mengukur implementasi kebijakan tersebut. Sementara perbedaannya terletak pada focus dan lokusnya dimana penelitian sebelumnya lebih berfokus kepada inovasi dan percepatan perizinan usaha dengan lokus di luar Provinsi Jawa Barat, sedangkan penulis lebih fokus membahas terkait pelayanan perizinan usaha dengan lokus di Kota Bandung dan Kabupaten Bandung yang sejauh pengetahuan penulis belum ada yang meneliti tentang implementasi OSS pada lokus yang Penulis ambil.

Berdasarkan fenomena-fenomena dan penelitian terdahulu yang telah penulis sampaikan sebelumnya, maka penulis tertarik untuk melakukan kajian terkait dengan implementasi Online Single Submission pada pelayanan perizinan usaha, dengan tujuan untuk dapat mengetahui sejauh mana teknis pelaksanaan OSS dan juga mengetahui faktor-faktor apa saja yang menghambat pelaksanaan OSS khususnya pada pelayanan perizinan usaha.

\section{Metode Penelitian}

Penelitian mengenai implementasi OSS pada pelayanan perizinan usaha di Kabupaten Bandung dan Kota Bandung ini menggunakan metode penelitian deskriptif dengan pendekatan kualitatif. Penulis juga melakukan wawancara dan pengamatan disertai partisipasi, sehingga memudahkan penulis untuk dapat melakukan komunikasi langsung dengan informan. Adapun terkait pengamatan yaitu dilakukan secara langsung oleh penulis dengan mendatangi instansi yang bersangkutan, dalam hal ini DPMPTSP Kabupaten Bandung dan Kota Bandung dengan maksud untuk mendapatkan berbagai informasi konkret terkait fakta yang terjadi di lapangan yang tentunya akan sulit diperoleh melalui cara lainnya.

Penelitian ini berfokus pada suatu kasus tertentu. Adapun identifikasi kasus yang dilakukan dibatasi pada kesiapan pemerintah Kota Bandung dan Kabupaten Bandung dalam implementasi OSS pada pelayanan perizinan usaha. Pengumpulan data dilakukan melalui wawancara mendalam dengan stakeholder terkait yaitu Kasubag Data dan Informasi DPMPTSP Kota Bandung, Sekretaris DPMPTSP Kabupaten Bandung, beberapa staff di lingkungan DPMPTSP Kota Bandung dan Kabupaten Bandung, serta beberapa pelaku bisnis yang pernah melakukan pelayanan perizinan usaha. selanjutnya, penulis melakukaan telaah 
terhadap hasil riset, PP No. 24 Tahun 2018 tentang Pelayanan Perizinan Berusaha Terintegrasi Secara Elektronik dan buku panduan yang berkaitan dengan OSS. Model Miles dan Huberman digunakan untuk melakukan analisis data dalam penelitian ini yaitu reduksi data, penyajian data, verifikasi, dan penarikan kesimpulan. Penulis memfokuskan pada hal-hal substantif yang berkenaan dengan objek penelitian dan membuang yang tidak perlu, kemudian menyajikan data menggunakan narasi dan melakukan penarikan kesimpulan yang diperoleh dari reduksi dan penyajian data yang telah dilakukan.

\section{Hasil dan Pembahasan}

Berdasarkan hasil pengamatan penulis di lapangan mengenai implementasi kebijakan Online Single Submission di Kota Bandung dan Kabupaten Bandung, apabila dihubungkan dengan teori yang dikemukakan oleh George C. Edward III, ditemukan dimensi-dimensi implementasi kebijakan yang perlu mendapatkan atensi, diantaranya adalah dimensi komunikasi, dimensi sumber daya, dimensi disposisi dan dimensi struktur birokrasi, berikut pelaksanaan kebijakan dari seluruh dimensi tersebut.

\section{Komunikasi}

Komunikasi adalah satu diantara 4 dimensi lainnya yang sangat menentukan dalam sebuah pelaksanaan kebijakan. Oleh karena itu, komunikasi yang baik harus terjalin diantara para implementor kebijakan, baik dalam satu unit pada sebuah instansi maupun implementor antar instansi terkait. Selain itu, komunikasi yang baik harus terjalin diantara para implementor kebijakan dengan target group yang mana dalam hal ini adalah semua masyarakat di lingkungan Kabupaten Bandung dan Kota Bandung.

Pelaksanaan kebijakan yang baik juga akan sangat tergantung pada komunikasi yang baik. Komunikasi yang dibangun juga harus mampu mengakomodasi setiap kepentingan yang ada, baik antar perumus kebijakan dengan implementor kebijakan dan pembuat kebijakan dengan publik yang dalam hal ini adalah masyarakat. Komunikasi juga sangat menentukan implementasi kebijakan yang pada akhirnya akan berimplikasi pada pencapaian tujuan dan output dari kebijakan tersebut.

Tujuan dari pelaksanaan kebijakan juga akan tercapai apabila standar-standar dan visi para pembuat kebijakan bisa dimengerti oleh masing-masing yang memiliki tanggung jawab untuk melaksanakan kebijakan. Oleh karena itu, sangat penting untuk memberikan atensi yang lebih kepada kejelasan standar-standar dasar dan cita-cita dari kebijakan tersebut, keakuratan komunikasi dengan seluruh implementor, tim, dan antar instansi yang terkait sangat krusial demi kelancaran pekerjaan masing-masing anggota organisasi, tim, dan antar instansi sehingga tidak adanya saling tunjuk, namun dapat saling mengisi satu sama lainnya.

Penulis menemukan salah satu kendala komunikasi yang dijumpai oleh Dinas Penanaman Modal dan Pelayanan Satu Pintu (DPMPTSP) Kota Bandung dan Kabupaten Bandung terdapat pada sosialisasi penerapan Peraturan Pemerintah No. 24 tahun 2018 tentang Pelayanan Perizinan Berusaha Terintegrasi secara Elektronik dimana perubahan aturan pelayanan perizinan begitu dinamis sehingga pemerintah daerah harus siap dengan segala kondisi yang akan dan sedang terjadi. 
Regulasi tersebut juga menjadi terkendala karena diterapkan tanpa adanya pasal peralihan atau aturan peralihan sejak diberlakukan pada bulan September 2018. Sehingga membuat Pemerintah Daerah baik Provinsi dan Kabupaten/Kota harus merevisi Perda dan Pergub dalam waktu yang relatif singkat. Selain itu, adanya desakan pemerintah terkait disusunnya regulasi cipta kerja yang merupakan sebuah regulasi dibentuk untuk menyasar sebuah isu besar yang mungkin dapat berdampak pada dicabut / diubahnya beberapa Undangundang secara bersamaan sehingga menjadi lebih elementer.

Berdasarkan informasi yang disampaikan oleh informan juga diketahui bahwa terdapat disharmoni aturan yang menyebabkan belum efektifnya kinerja pelayanan yang dilakukan oleh Pemerintah Daerah. Disharmoni yang dimaksud disini adalah regulasi-regulasi yang digunakan saat ini belum disesuaikan dengan perubahan mekanisme izin yang baru. Semua izin-izin terkait dengan usaha terhubung dengan aplikasi OSS. Meskipun konsepnya sudah bagus, namun detailnya terlihat belum harmonis. Dimana setiap perizinan yang berkaitan antar Kementerian / Lembaga masih belum harmonis atau bahkan yang sudah keluar pun masih harus ditinjau kembali misalnya yang berkaitan dengan tata ruang.

Pemerintah Daerah dalam hal ini Pemerintah Kota Bandung dan Kabupaten Bandung dituntut untuk dapat menyesuaikan aturan diatasnya sehingga perlu mengeluarkan regulasi yang berkaitan dengan perizinan. Contohnya Pemerintah Kabupaten Bandung mengeluarkan Peraturan Bupati Nomor 16 Tahun 2019 tentang Pendelegasian Wewenang Penyelenggaraan Pelayanan Perizinan dan Non Perizinan Kepada Kepala Dinas Penanaman Modal Dan Pelayanan Terpadu Satu Pintu Kabupaten Bandung sebagai upaya pemerintah dari melaksanakan amanah dari pemerintah pusat tentang pelayanan izin terpadu. Begitu juga dengan Pemerintah Kota Bandung yang telah menerbitkan Peraturan Walikota Nomor 24 Tahun 2019 tentang Perubahan Ketiga Atas Peraturan Wali Kota Bandung Nomor 235 Tahun 2017 Tentang Standar Operasional Prosedur Penanaman Modal Dan Pelayanan Terpadu Satu Pintu. Meski telah memiliki regulasi, penataan kembali aturan perizinan berusaha perlu dilakukan, untuk dapat memberikan landasan hukum bagi penerbitan legalitas usaha secara elektronik dan terintegrasi, selain itu penataan kembali persyaratan/ perizinan lainnya bagi pelaku bisnis yang terdapat pada beberapa peraturan perundang-undangan.

\section{Sumber Daya}

Pelaksanaan kebijakan bisa saja dilaksanakan secara konsisten, cermat, dan jelas. Namun apabila terjadi kekurangan sumber daya yang dimiliki oleh organisasi/birokrasi akan berdampak pada kurang efektifnya pelaksanaan kebijakan tersebut. Dengan begitu, dapat dipahami bahwa kehadiran sumber daya ini sangat berpengaruh pada sebuah institusi (R. R. T. Abubakar, 2018). Hal ini dapat dipahami karena sumber daya dalam sebuah kebijakan adalah faktor yang paling krusial.

Sumber daya juga menjadi salah satu aspek yang wajib mendapatkan perhatian lebih karena tanpa sumber daya sebuah kebijakan hanyalah formula yang tidak akan memliki dampak apapun apalagi dalam hal memecahkan persoalan-persoalan masyarakat. Kompetensi aparatur, sarana prasarana, dan anggaran wajib ada dan betul-betul dipersiapkan agar dapat menghasilkan output yang sesuai dengan harapan.

Terdapat beberapa faktor sumber daya yang berpengaruh dalam proses implementasi kebijakan OSS yang tentunya akan sangat berguna sebagai penunjang kelancaran dan efektivitas Implementasi kebijakan. Yaitu : (1) Staff. yang merupakan salah satu dari beberapa

Joni Dawud, Rodlial Ramdhan Tackbir Abubakar, Deni Fauzi Ramdani 
sumber daya yang kehadirannya sangat krusial dalam implementasi kebijakan. Kecukupan jumlah staff tidak dengan sendirinya mendorong tercapainya suatu tujuan dari kebijakan. Begitu pula sebaliknya apabila terdapat kekurangan staff. Sehingga kedua hal tersebut perlu diperhatikan dalam penerapan kebijakan atau program pemerintah. Karena tanpa keahlian, akan membuat pelaksana kebijakan terlihat kurang profesional. Sedangkan anggaran dapat menjamin kelangsungan kebijakan atau program. Sehingga tanpa adanya dukungan anggaran yang cukup, sebuah kebijakan ataupun program tidak akan efektif dan efisien dalam mencapai sasaran dan tujuan (Dwiyanto, 2009).

Sumber daya kebijakan dalam implementasi kebijakan One Single Submission di Kota Bandung dan Kabupaten Bandung sebetulnya dapat dikatakan cukup baik, dilihat dari segi kuantitasnya dan juga kualitasnya. Namun terdapat salah satu kendala yaitu terkait perbaikan infrastruktur IT, dimana Pemerintah Daerah harus memfasilitasi pemohon izin dengan 3 kriteria; (1) Loket berbantuan, pada segmen ini pemohon harus dibantu daftar sampai dia dapat izin dengan kriteria-kriteria tertentu. (2) Loket mandiri, dimana pihak DPMPTSP menyiapkan komputer didepan dan masyarakat sebagai pemohon bisa akses sendiri (self-access). (3) Loket prioritas, yang diperuntukan bagi seseorang yang akan berinvestasi dalam jumlah besar sehingga memerlukan perlakuan khusus. Ini merupakan intruksi presiden langsung, dimana pemberi layanan memberikan pelayanan VVIP dengan ruangan khusus sehingga membuat setiap orang nyaman dalam proses perizinan.

Selanjutnya terkait dengan Informasi, dimana dalam sebuah pelaksanaan kebijakan informasi memiliki dua jenis, yaitu pelaksanaan yang berhubungan dengan cara mengimplementasikan kebijakan dan informasi mengenai data kepatuhan masyarakat terhadap aturan pemerintah yang telah disahkan.

\section{Disposisi}

Disposisi sangat berkaitan dengan karakteristik atau watak yang dimiliki oleh implementor, seperti sifat demokratis, kejujuran, dan komitmen. Dimana para implementor kebijakan harus terhindar dari segala bentuk penyalahgunaan jabatan, korupsi dan kolusi serta menjamin adanya praktik organisasi yang sehat. Berdasarkan hasil wawancara dengan informan, Sampai saat ini aturan mengenai kedisiplinan dalam pelayanan terkait dengan tugas kepegawaian dalam pembinaan betul-betul ditegakkan. Tercatat misalnya di Dinas Penanaman Modal dan Pelayanan Terpadu Satu Pintu Kabupaten Bandung itu ada bagian dari SPIP, teguran lisan sampai tertulis, usulan sanksi menurut informan itu berlaku umum diberlakukan pada petugas pelayanan maupun terhadap petugas diluar pelayanan. Sehingga terdapat aturan main yang adil bagi siapa saja yang melakukan pelanggaran.

\section{Struktur Birokrasi}

Birokrasi dalam pelayanan legalitas usaha seringkali mematok harga yang cukup tinggi, hal ini disebabkan karena adanya biaya illegal dalam proses pengurusan legalitas usaha tersebut yang tentunya akan mempengaruhi iklim investasi yang ada (Hasibuan, 2017). Dalam pelaksanaan kebijakan Open Single Submission di Kabupaten Bandung dan Kota Bandung terlihat adanya sinergitas antara atasan dan bawahan di dalam instansi, baik itu mengenai persamaan pandangan tentang program tersebut, maupun terkait teknis pelaksanaannya. Seperti halnya di Kota Bandung, dimana Walikota Bandung telah menyampaikan segala informasi kepada para stakeholder agar terciptanya persamaan pandangan, visi serta misi yang telah ditetapkan sebelumnya. Karena jika tidak dilakukan, maka implementasi kebijakan ini 
akan menjadi bias dengan sendirinya sehingga akan menciptakan gaya komunikasi yang kurang baik dan berdampak pada kesenjangan implementasi.

Hal ini diperkuat dengan pernyataan salah satu informan yang menyatakan bahwa "Telah terjalin sinergitas di setiap perangkat daerah, karena sudah ada BCC mini yang langsung terhubung ke BCC pusat yang berada di Dinas Komunikasi dan Informatika Kota Bandung disertai dengan adanya tenaga-tenaga IT yang kompeten dalam menjalankan sistem atau aplikasi sehingga memudahkan dalam melakukan koordinasi."

DPMPTSP mengelola organisasinya dengan membangun sistem yang benar yang tidak dimungkinkan adanya intervensi manual yang dapat merusak sistem kerja. Oleh karena itu, DPMPTSP terus menyempurnakannya melalui Otomatisasi proses kerja. Sebagaimana yang dilakukan di DPMPTSP baik Kabupaten Bandung maupun Kota Bandung. Masing-masing sudah menerapkan sistem manajemen kerja yang efektif dalam melakukan pelayanan yaitu dengan menggunakan proses pelayanan dengan proses digitalisasi. DPMPTSP Kabupaten memiliki aplikasi SAMIRINDU yang didalamnya terdapat berbagai menu pelayanan. Begitu juga DPMPTSP Kota Bandung yang telah menyediakan berbagai perizinan online yang tersedia pada website https://dpmptsp.bandung.go.id/. Dalam pelaksanaanya penulis menilai pola manajerial DPMPTSP Kota Bandung relatif lebih rapi dibandingkan dengan DPMPTSP Kabupaten Bandung. Sistem yang tersedia akan memudahkan masyarakat dan pemberi layanan dalam melakukan proses izin. Sehingga dengan menggunakan aplikasi tersebut memungkinan pemberi layanan untuk melakukan verifikasi melibatkan pihak dinas teknis tanpa harus membawa sumberdaya pegawai tersebut ke DPMPTSP.

\section{Hambatan Implementasi Open Single Submission di Kabupaten Bandung dan Kota Bandung}

Hambatan-hambatan yang ditemui pada implementasi kebijakan OSS di Kabupaten Bandung dan Kota Bandung dapat kita lihat dari dimensi komunikasi, dimensi sumber daya, dimensi disposisi, dan dan dimensi Struktur birokrasi yaitu sebagai berikut :

a. Komunikasi, berkaitan dengan sosialisasi yang belum tersampaikan secara merata dan mengakibatkan belum tersampaikannya informasi terkait dengan online single submission kepada masyarakat serta pihak-pihak yang terkait. Selain itu kurangnya publikasi terkait dengan sistem dan aplikasi yang telah dibuat oleh pemerintah kepada masyarakat, menyebabkan masih adanya masyarakat yang belum mengetahui terkait keberadaan sistem maupun aplikasi tersebut.

b. Sumber daya, DPMPTSP Kabupaten Bandung merasakan kekurangan Sumber Daya Manusia (pegawai) terutama dalam hal perizinan. Karena idealnya 1 orang Kasi memiliki minimal 3 orang staf. saat ini terdapat 6 kasi yang mana masing-masing kasi memiliki 1 atau 2 staf. Semua perizinan terkait DPMPTSP bussines process dilaksanakan di DPMPTSP. Jadi, meskipun sudah ada pendelegasian kewenangan perizinan dari perangkat teknis tidak disertai dengan petugas teknis yang sudah ahli.

c. Disposisi, aturan mengenai kedisiplinan dalam pelayanan terkait dengan tugas kepegawaian dalam pembinaan betul-betul ditegakkan, sehingga dalam hal ini tidak terjadi hambatan yang berarti pada dimensi disposisi.

d. Struktur Birokrasi, hambatan pada dimensi ini yaitu terletak pada struktur baru DPMPTSP Kabupaten Bandung saat ini menyesuaikan dengan kebutuhan yang 
disesuaikan dengan dinamika perubahan regulasi yang ada. Yaitu dengan menambahkan bidang pengaduan, advokasi dan peningkatan layanan. Ini adalah salah satu bidang baru, yang muncul berdasarkan pengalaman, karena selama ini bidang izin ini tidak fokus memberikan pelayanan karena harus menyelenggarakan tugas-tugas lain diluar pelayanan langsung. Bidang izin ini juga sibuk dalam menafsirkan peraturan, membuat SOP, membuat SP, dan melayani pengaduan. Karena itu kurang optimal dalam memberikan pelayanan waktunya habis dengan urusan lain.

\section{Simpulan}

Berdasarkan pada hasil dan pembahasan penelitian, dapat disimpulkan bahwa implementasi Open Single Submission oleh DPMPTSP Kabupaten Bandung dan Kota Bandung secara umum sudah berjalan dengan baik. Hal ini dapat terlihat dari adanya Regulasi turunan yang telah diterbitkan oleh masing-masing Pemerintah Daerah tersebut yang digunakan sebagai landasan hukum pelaksanaan OSS, memiliki kualitas aparatur yang cukup mumpuni dalam menjalankan OSS, telah dibentuk petugas khusus untuk memberikan sanksi pagi para petugas yang melakukan pelanggaran dalam pelayanan, serta proses pelayanan yang ada sudah dilakukan dengan proses digitalisasi. Hanya saja masih terdapat kendala yang sering dihadapi oleh DPMPTSP Kota Bandung dan Kabupaten Bandung, terutama terkait dengan permasalahan sosialisasi, kekurangan Sumber Daya Manusia untuk membantu berbagai pelayanan lainnya, dan fasilitas pendukung lainnya dalam rangka mengoptimalkan implementasi OSS.

Penulis menyadari bahwa suatu penelitian tidak bisa lepas dari sebuah keterbatasan, oleh karena itu penulis menyampaikan rekomendasi yang perlu diperhatikan pada penelitian selanjutnya (further research) sebagai berikut:

1. Objek penelitian yang masih terbatas, di mana penelitian ini baru berhasil mendapatkan informan di Lingkungan DPMPTSP Kabupaten Bandung dan Kota Bandung. Penulis menyarankan agar penelitian lebih lanjut dapat memperluas jangkauan informan, misalnya kepada pelaku bisnis yang belum/enggan untuk melakukan perizinan usaha.

2. Penelitian ini dilakukan menjelang akhir tahun, saat instansi yang bersangkutan sedang memiliki banyak kesibukan; sehingga berpengaruh terhadap feedback yang penulis dapatkan kurang kondusif. Penulis menyarankan agar penelitian yang akan dilakukan di masa mendatang dimulai sejak awal tahun, sehingga tingkat kesediaan informan sebagai objek dan subjek penelitian akan lebih tinggi.

3. Terkait dengan implementasi OSS sendiri penulis menyarankan agar penelitian selanjutnya perlu berfokus pada integrasi sistem OSS yang telah ada sekarang dengan sistem pelayanan yang telah dimiliki oleh Pemerintah Daerah. 


\section{Referensi}

Abubakar, R. (2019). Implementation of the Child Identity Card Policy in Bandung Regency. Good Governance, 15(1).

Abubakar, R. R. T. (2018). The Influence Of Employee Competency To Productivity Employees Of Health Bandung Office. Administrasi Negara, 24(1), 17-32.

Assegaf, Julianti, \& Sa'adah. (2019). Pelaksanaan Online Single Submission (OSS) dalam Rangka Percepatan Perizinan Berusaha di Dinas Penanaman Modal Dan Pelayanan Terpadu Satu Pintu (DPMPTSP) Jawa Tengah. Diponegoro Law Journal, 8(2).

Dwiyanto. (2009). Perbandingan Administrasi Publik. Bandung: Gava Media.

Fadhilah, A. N., \& Indah Prabawati. (2019). Implementasi Pelayanan Perizinan Berusaha Terintegrasi Secara Elektronik Online Single Submission (OSS) Studi Pada Dinas Penanaman Modal dan Pelayanan Terpadu Satu Pintu (DPMPTSP) Kabupaten Nganjuk. Publika, 7(4).

Hasibuan, B. M. (2017). Investasi dan Sejarah Perkembangan Investasi Asing di Indonesia.

Izhandri, \& Harahap. (2019). OSS dan Perkembangannya di Indonesi. Magister Kenoktariatan USU.

Maulida. (2019). Efektivitas Penerapan Online Single Submission (OSS) Pada Dinas Penanaman Modal dan Pelayanan Terpadu Satu Pintu Kabupaten Pelalawan. UIN Sultan Syarif Kasim Riau.

Nugroho. (2012). Public Policy for the developing Countries. Yogyakarta: Pustaka Belajar.

Pikri, Abubakar, \& Adawiyah. (2019). Implementasi Peraturan Bupati Purwakarta No. 69 Tahun 2015 Tentang Pendidikan Berkarakter. Publica, 11(1), 12-19.

Robby, \& Tarmini. (2019). Inovasi Pelayanan Perizinan Melalui Online Single Submission (Oss) : Studi Pada Izin Usaha Di Dinas Penanaman Modal Dan Pelayanan Terpadu Satu Pintu (Dpmptsp) Kabupaten Bekasi. Administratio, 10(2).

Sembiring, S. (2018). Hukum Investasi. Bandung: CV. Nuansa Aulia.

Sutedi. (2010). Hukum Perizinan : Dalam Sektor Pelayanan Publik. Jakarta: Sinar Grafika. 